
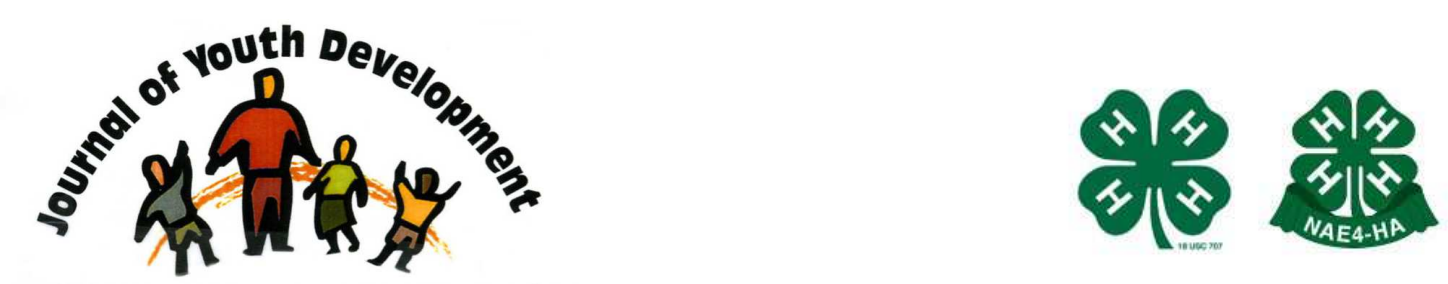

Bridging Research \& Practice

\title{
Investing in Professional Development: Building and Sustaining a Viable 4-H Youth Workforce for the Future
}

\author{
Kirk A. Astroth \\ 4-H Youth Development \\ The University of Arizona \\ Tucson, AZ \\ kastroth@cals.arizona.edu \\ James Lindstrom \\ WSU Professional Development \\ Washington State University \\ Spokane, WA \\ jlindstr@wsu.edu
}




\title{
JOURNAL OF YOUTH DEVELOPMENT \\ bridging research and practice

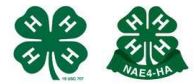

Volume 3, Number 2, Fall 2008

Article 080302FA001

\section{Investing in Professional Development: Building and Sustaining a Viable 4-H Youth Workforce for the Future}

\author{
Kirk A. Astroth \\ The University of Arizona \\ James Lindstrom \\ Washington State University
}

\begin{abstract}
Positive youth development outcomes are influenced by a competent, highly trained work force that enjoys their work with young people. The youth work field has struggled with how to keep and motivate front line youth workers given the heavy workloads, low pay, lack of recognition and irregular time demands to compete with family responsibilities. Professional development is a key strategy for retaining and motivating youth workers. A model of professional development called the Western 4-H Institute has been developed and held now for two sessions. Results from participants indicate that this strategy can have a positive influence on job satisfaction, competencies, and retention. In fact, only 10 percent of participants had left during the intervening 5 years, and job satisfaction had increased significantly over time. Organizational loyalty among participants is not high, but with early career professionals, they may still be trying to find their niche. A regional training model has shown itself to be effective in supporting 4- $\mathrm{H}$ youth professionals and is building a sustainable workforce for the future.
\end{abstract}

\section{Introduction}

The youth work profession has both challenges and opportunities. First and foremost, youth work is characterized by high turnover. Youth work often does not pay as well as other career choices, so that the young, energetic individuals attracted to this work in the first place often leave for other jobs which offer more financial compensation. Second, youth work entails long and irregular hours-hours that disrupt family lives of the professionals as well as the participants. However, in the case of the former the sacrifice is required while for the families it 
is a choice. Burnout is often cited as a reason for leaving by frontline youth workers (Laroche \& Klein, 2008; Yohalem, Pittman, \& Moore, 2006). And finally, youth work is so hectic and time demanding that training is sometimes sacrificed to direct service. Front line workers often have inadequate support and ongoing professional development to keep them current and motivated (Garza, Borden \& Astroth, 2004).

These factors, among others, can translate into high turnover and low job satisfaction. Nearly every youth service organization has searched for ways to recruit, retain and sustain youth workers. As one national report framed it, burnout, extreme work loads, long hours and high turnover are all elements for the most talented youth workers (Casey Foundation, 2003). On top of this, our society continues to undervalue youth workers and their contributions to developing contributing adults of the future.

Yet, good youth work demands a highly skilled, knowledgeable work force (Stone, Garza \& Borden, 2005). In fact, a national study described the critical link between positive youth outcomes and relationships with front line youth workers (Bouffard \& Little, 2004). This report also suggested that investing in the professional development of youth worker staff can positively impact the sustainability of the youth development work force. Others have also documented the importance and value of professional development for youth workers (Bowie \& Bronte-Tinkew, 2006). At the same time, however, there is a lack of information about the relationship between positive youth development outcomes and professional development training of staff.

While there are many programs designed to meet the professional development needs of front line youth workers, there is a dearth of information about the impacts of these efforts.

First, can investments in the professional development of youth workers result in identifiable benefits? Specifically, can efforts to train and support front line youth workers make impacts on job satisfaction, turnover, burnout and retention?

Second, what is the relationship between professional development training for frontline youth workers to youth development outcomes?

These were just some of the questions we sought to address in a regional training approach designed for early career 4-H professionals.

\section{Situation}

In many of the 13 Western states, professional development training for $4-\mathrm{H}$ professionals is a significant challenge because of small staff numbers, long times between hiring, great distances in many Western states and limited training budgets. As a result, professional development training comes long after youth workers are hired, content is often generic rather than specific, and opportunities for networking are limited to a just a few colleagues. Like other areas of the country, front line 4-H youth work professionals are often hired without much previous field experience, and they often have to wait years for core training that can help them succeed. Often, these in-state training experiences are short, quick-fix approaches that serve to address immediate programmatic and policy requirements rather than developing critical competencies. If positive results occur, it is likely more attributable to chancy causation than intentionality. Authentic professional development should be systematic and ongoing. 
Moreover, some state 4-H program leaders have found that newly-hired 4-H agents often lack an understanding of the 4- $\mathrm{H}$ club program and its value in youth development. A training regime which would provide a common grounding and support for why clubs still matter as a viable delivery method would be valuable to cultivating professionals' support for sustaining this important avenue of participation (Walker, Dunham \& Snyder, 1998).

In 2000 , the $4-\mathrm{H}$ program directors of the 13 Western states were approached to support a regional professional development initiative designed to build a common basis of competencies and skills for 4-H professionals throughout the region and improve retention and job satisfaction. Our belief was that only through a larger effort, pooling resources to realize an economy of scale, could the 4-H system impact job retention, satisfaction and reduce burnout and turnover.

\section{Curriculum Design and Implementation}

Following a commitment of financial support from Western 4-H program leaders, a design team was assembled to develop a curriculum for an intensive 4-day training regime for early career 4-H youth professionals. Content for the curriculum included elements from each of the existing 4-H Professional Research and Knowledge (4-H PRK) taxonomy domains at that timeyouth development, youth program management, volunteerism, communication and educational design (Hastings \& Lifer, 1988). In addition, survival tips, priority setting and policy issues were also included. Significant time was also allotted for networking and camaraderie.

The first Western 4-H Institute, as the program was ultimately titled, was held in April 2002 on the campus of Utah State University. At this initial professional development training, 76 professionals from nearly all 13 Western states participated. A second Western 4-H Institute was held in February 2006 in Las Vegas, Nevada. A summary evaluation of this first cohort was published in 2002 (Astroth, 2002). A wealth of information about this first cohort was collected regarding demographic profiles, job satisfaction, competencies, professionalism and time spent at work. Additionally, institute participants had the opportunity to respond to open ended questions regarding their experience in planning the 2006 institute (Lindstrom, 2004).

The curriculum for the second Institute was revised slightly following revisions to the 4-H PRK taxonomy to align more with competencies-hence renamed 4-H Professional Research and Knowledge Competencies (4-H PRKC). This revised taxonomy includes 6 domains:

1. volunteerism;

2. youth development;

3. youth program management;

4. access, equity and opportunity;

5. organizational systems; and

6. partnerships (Stone \& Rennekamp, 2004)

Sixty-one professionals participated in this professional development training. A summary evaluation of the second cohort was compiled in 2006 (Webb, et al., 2006). The evaluation results from this report supported the results from the report of the 2002 Institute.

In 2007, we surveyed participants from both cohort groups to try and understand the influence of the training on the participants themselves. We were especially interested in turnover, job 
satisfaction, skill development and career options. Of the original 137 participants, we were able to collect email addresses for 131 professionals.

A third Institute is planned for February 2009, so we were anxious to survey the first two cohorts in order to gain any insights which could be applied to the next professional development training.

\section{Results}

During the Institute, we had collected email addresses from all participants, and so contacting them through a Survey Monkey tool was easy. Over a period of months, a survey tool was designed to include questions from post-Institute evaluations as well as unique questions to assess job satisfaction, skill development, career advancement and future career aspirations. The questions were submitted to $4-\mathrm{H}$ professionals for face validity.

The survey was launched in the spring of 2007 and left open for a period of one month. Several reminders were sent to non-respondents to enlist their participation. Bounced emails were pursued with individual state leaders to ascertain job status for specific individuals.

\section{Demographics}

In the end, 70 participants completed the survey-a response rate of 51 percent. Of those responding, 70 percent were female, 58 percent had earned a master's degree while 26 percent had earned a bachelor's degree. About 10 percent had only a high school diploma or associate's degree. Six percent had earned doctorate degrees.

Of those responding to the survey, 59 percent were county agents/educators, while 22 percent were program coordinators, assistants or para-professionals of some kind. About 10 percent were district/area agents or specialists, and just 4 percent were state specialists. The remainder of participants were represented by state $4-\mathrm{H}$ program leaders, program aides or others.

\section{Turnover}

Of this original set of 131 professionals, 13 had quit-a turnover rate of 10 percent. Some of the participants had quit and gone on to other careers; others we simply could not locate.

\section{Career Advancement}

One of the areas we wanted to learn more about was whether participants had risen in the ranks since their participation in the Institute. Nearly 60 percent of respondents from the two cohort groups were at the same level as when they participated in the Institute. However, 27 percent had increased in position or responsibilities while 7 percent had transitioned completely out of 4-H responsibilities but still worked for Extension in some other capacity. One participant, for example, had been promoted to County Extension Director in a large, metropolitan county.

\section{Job Satisfaction}

As a result of this intensive professional development experience, how satisfied were participants with their jobs? Were they more frustrated, or were they looking for other jobs? A series of question sought to find answers to these questions. 
When we inquired about participants' current level of job satisfaction, 69 percent indicated that they were "satisfied" and another 16 percent indicated that they were "very satisfied."

Seventeen percent indicated that they were neutral-neither dissatisfied nor satisfied (See Table 1).

\section{Table 1}

Job satisfaction levels of respondents at the time of survey

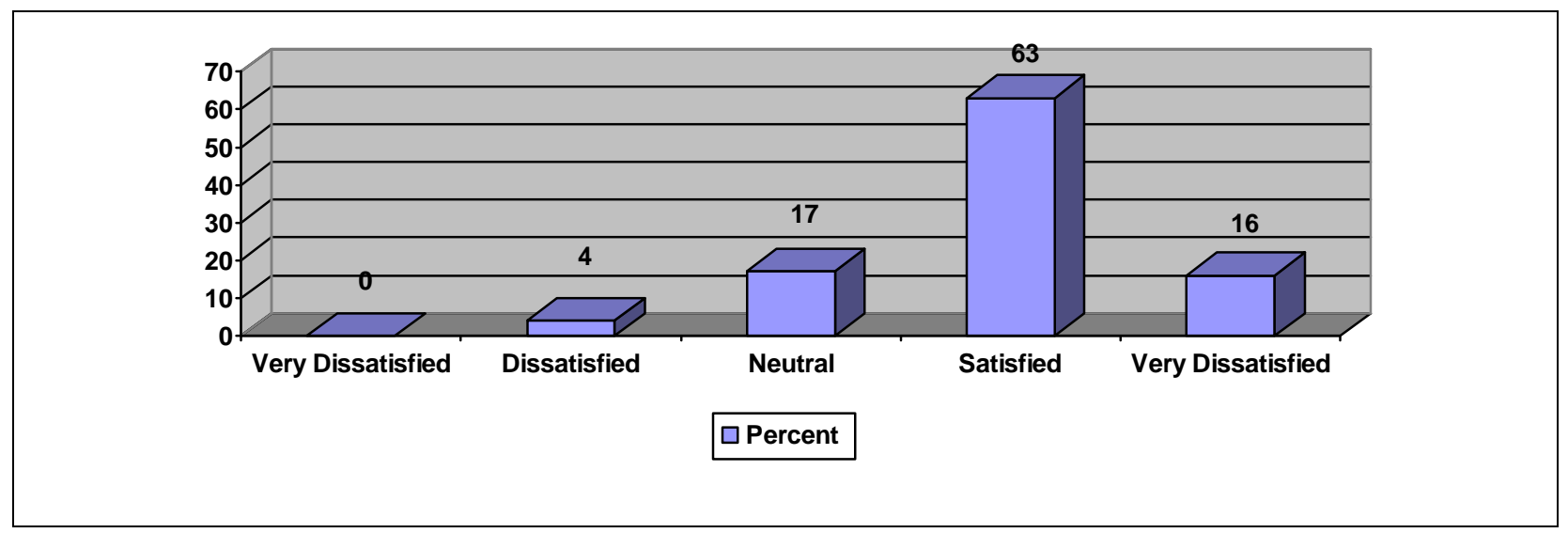

Using a post-then-pre design, we also asked participants about their level of job satisfaction at the time in which they were enrolled in the Institute. Their responses are found in Table 2.

Table 2

Job satisfaction of Institute participants at the time they were involved in the Institute

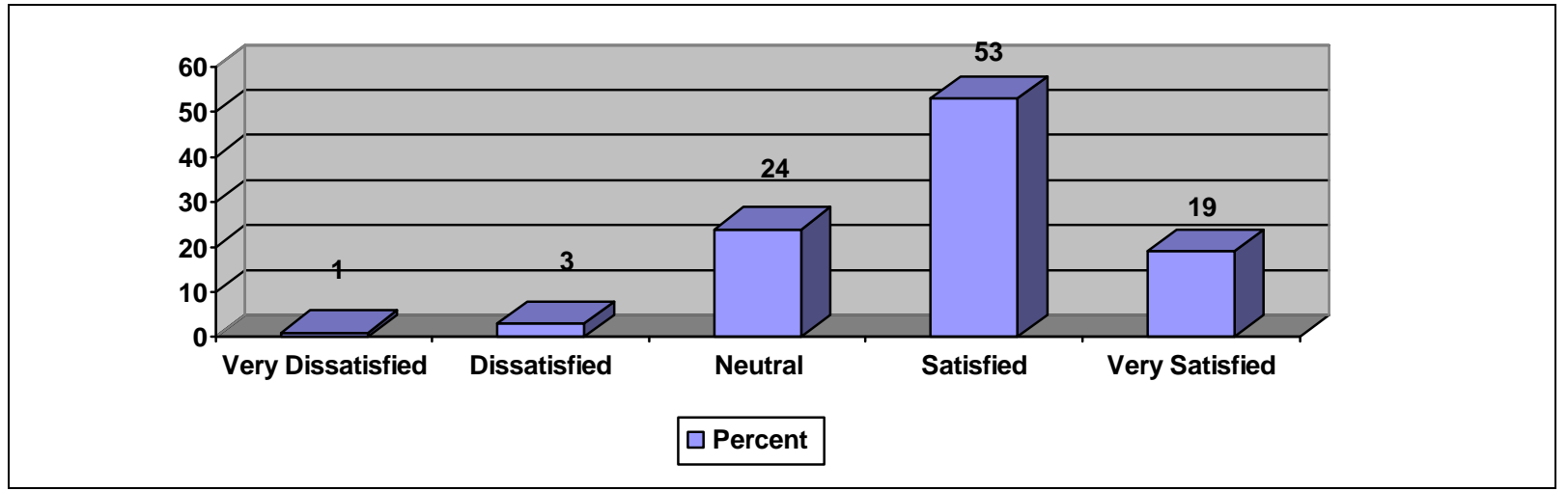

Finally, we simply asked participants if their jobs were enjoyable. Nearly four out of five respondents agreed with this statement ( 80 percent) while only 17 percent indicated that they were neutral on this question. Less than 3 percent disagreed with this characterization of their job environment.

\section{Competencies and Confidence}

Several questions sought to gain insights into the professional competencies and skills. When asked whether their participation in the Institute has enhanced their skills to work in 4-H youth development, nearly half (49 percent) said "to a good extent." Nearly a third indicated that the 
Institute had "adequately" enhanced their professional skills. Fourteen percent indicated that the Institute had only a limited influence on their professional skills.

With respect to changes in self-confidence to manage and lead a 4-H program as a result of the Institute training, 43 percent indicated that they had "moderate confidence" while another 39 percent indicated that they had "high confidence." Only 3 percent ( 2 respondents) indicated that they were "not at all confident."

We wanted to learn to what extent participants found the Institute training valuable to them in developing professionally as a 4-H practitioner. A large number of the respondents from both cohorts indicated that the training was "highly valuable" to them-44 percent of the total. Another 11 percent said the training was very valuable toward this goal, while another 11 percent indicated that the Institute training had limited value to them as a $4-\mathrm{H}$ practitioner. No one indicated that the training had no value at all.

\section{Retention}

A series of questions sought to understand the intrinsic motivations of participants related to staying with a career in Extension. When asked if "I would be very happy to spend the rest of my professional career with Extension working in 4- $\mathrm{H}^{\prime \prime}$ (emphasis added), over half of the respondents indicated a positive response. However, nearly a fourth of respondents indicated that they did not see themselves spending their career in 4-H Extension work. Another 17 percent were not sure (see Table 3).

Table 3

Percent of respondents who indicated their satisfaction with staying in a 4-H career with Extension

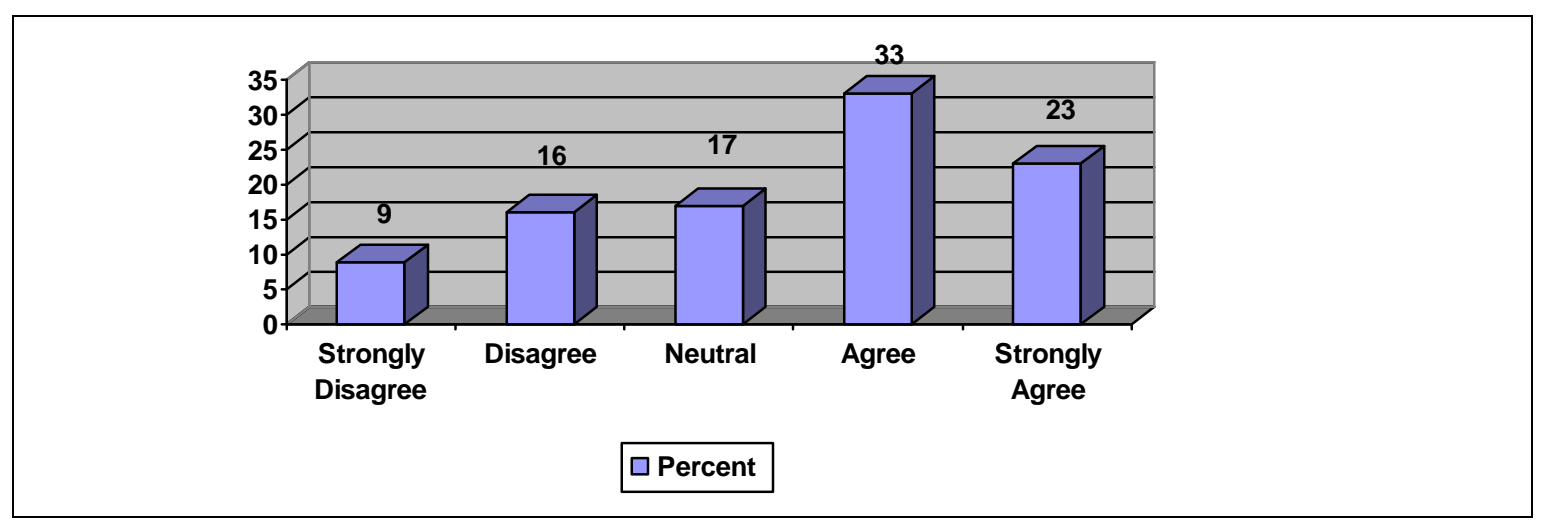

In another series of questions, we also sought to probe feelings of organizational loyalty, sense of belonging, and range of employment options from the participants' point of view. For example, Extension employees often talk about Extension being a "family" that looks out for one another and supports each other. One question, then, asked respondents if they felt "part of the family" in Extension. Half of all respondents agreed with this assessment, and another 13 percent strongly agreed. About one-fourth were neutral on this question, while 14 percent disagreed with this characterization.

Because a job with Extension may have been many respondents' first "real" career offer, we asked how obligated these new employees felt to remain employed with Extension. Interestingly, 38 percent did not express any obligation to remain with Extension, and another 
20 percent were undecided. However, thirty-nine percent agreed with this assessment (see Table 4).

Table 4

Percent of respondents who expressed an obligation to remain with Extension as their employer

\begin{tabular}{|l|c|l|l|l|l|c|}
\hline & $\begin{array}{l}\text { Strongly } \\
\text { Disagree }\end{array}$ & Disagree & Neutral & Agree & $\begin{array}{l}\text { Strongly } \\
\text { Agree }\end{array}$ & Not sure \\
\hline Percent & 14.3 & 24.3 & 20.0 & 28.6 & 11.4 & 1.4 \\
\hline
\end{tabular}

Another question sought to uncover whether current employees felt trapped in their current career path with few options. To what extent were some of these employees staying with Extension because of perceived limited career options? The majority of respondents felt that they had other options but were intentionally choosing to stay with their career in Extension. Over 50 percent, for example, disagreed with the statement that they had "too few options to consider leaving Extension." However, fewer felt that staying with Extension was just as much a matter of desire as a matter of necessity. About a third indicated that they felt they had limited option in their current position-because of family, cost of living or other factors.

Asked if their job was "the best job I have ever had," only 11 percent disputed this statement while half agreed. However, the jury is still out for a significant portion-fully 39 percent were neutral on this statement.

For these new employees, loyalty to Extension is still not strongly embedded as it might be for longer-term faculty and staff. In response to a question about whether it would be wrong to leave Extension now, even if there were benefits to them personally, nearly 60 percent said they would leave Extension if it were to their advantage. However, a fifth of the respondents indicated that they felt compelled to remain employed with Extension, even if it were to their advantage to move on. Another one-fifth of respondents were neutral on this question.

When asked if they would be looking for a new job within the coming year, half of the respondents said that this was not at all likely. Yet a sizeable portion thought that this scenario was a likely event in the next year.

Finally, we asked how often these participants thought about quitting. One third reported that they thought about this once in a while, but another third said "rarely." One fifth (20 percent) said "occasionally." 


\section{Table 5}

Percent of respondents who thought about quitting

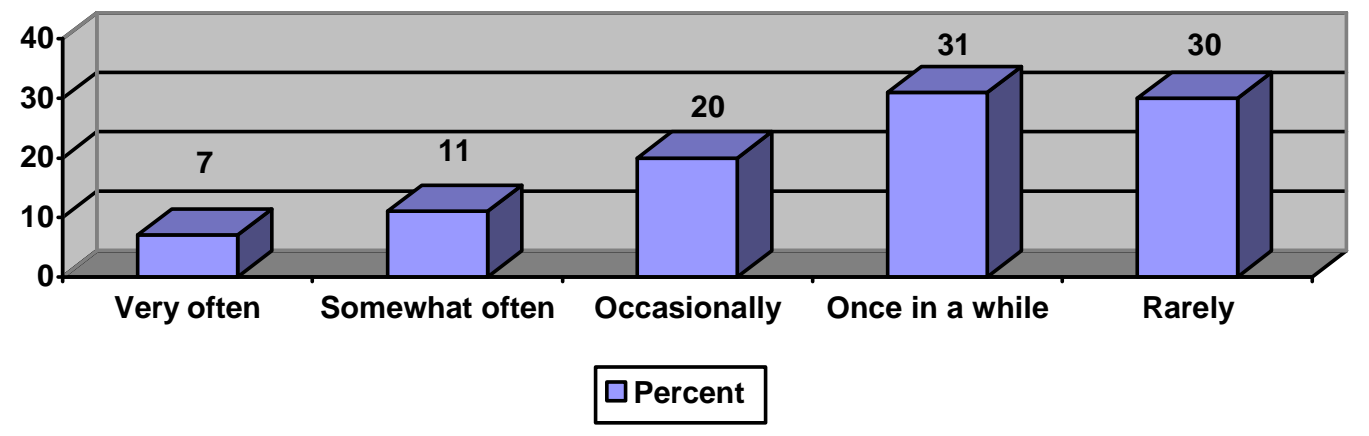

\section{Work Environment Relationships}

One of the areas we were curious about was whether the advanced training in the theory and practice of positive youth development affected relationships with co-workers. We were concerned that after receiving such in-depth training that these new insights and skills might create a distance or alienation with co-workers. Fortunately, this did not seem to be the case for most participants. In fact, nearly half (44 percent) disagreed that they were somehow in a different place philosophically from co-workers as a result of the Institute training. Twentyeight percent were neutral on this assessment, and only 17 percent agreed that they now had trouble relating to co-workers as a result.

\section{Discussion}

Demographics. As with other studies of 4-H youth workers, the ranks are heavily weighted towards female employees. Nearly three-fourths of respondents were women while only a third were male. Most have earned a master's degree-again attesting to the high level of education that 4-H youth workers bring to their avocations. This higher level of education provides $4-\mathrm{H}$ with a strategic advantage compared to other youth organizations. Whether it translates into higher program quality has yet to be documented.

Turnover and Retention. Youth work can be stressful, challenging work but at the same time it can be very rewarding work. Youth workers typically are paid less than other professionals and often work long hours-including evenings and weekends. These elements--long hours, modest compensation, stressful work environments-are not ingredients for increasing retention or staff stability.

What do we know about employee satisfaction in general? A recent national survey by Salary.com of more than 15,000 employees in all fields found that 65 percent of them plan to leave their current positions in the next three months. Lower paid employees are 66 percent more likely to look for a new job than highly paid employees. Specifically, employees earning less than $\$ 40,000$ per year are approximately 25 percent more likely to look for a new job than the average employee (Salary.com, 2006).

Moreover, this survey of national employees found that the most common reasons for wanting to leave their current job were (1) inadequate compensation (57\%) and (2) no opportunities for 
advancement (37\%). Insufficient benefits or poor working hours were also cited as reasons for leaving a job by less than 1 in 5 workers (Salary.com, 2006).

Employee turnover is expensive. Human resource professionals "estimate that turnover costs 26.8 percent of the annual salary of the person being replaced" (Salary.com, 2006). But other estimates of turnover costs are much higher-as much as 50 percent to more than several times the worker's salary, depending on the person who must be replaced. To anyone who has conducted a search for a staff position, they know that replacing staff is an expensive and longdrawn out endeavor. Training and orientation time alone are quite expensive.

Surveys of youth workers have found that the youth work field is particularly prone to high turnover and other challenges. For example, the Beacon Workforce Study in San Francisco found that workforce retention, sporadic opportunities for professional development and ongoing funding issues were characteristic of the youth workers' environment in the Bay area. While many found their work highly satisfying and full of purpose and meaning, many professional youth workers did not stay in the field long because "pay is insufficient or incommensurate with their education, because they don't see a clear career ladder...and because Youth Development work can be emotionally depleting for many" (Resource Development Associates, 2006, p. 4).

Not surprisingly, youth work is often plagued by high rates of turnover and low retention. As a result, the youth development field, in general, is characterized by young, inexperienced people hanging on while looking for other, better opportunities. The Beacon survey of youth workers in San Francisco, for example, found that 72 percent of respondents found their work to be stressful--much higher than national finding where only 34 percent feel work is stressful (Resource Development Associates, 2006).

Despite the reputed high turnover in youth worker ranks, however, only 10 percent of the respondents from the Institute group had left for other employment even including the cohort that began in 2002. Of course, there could be several explanations for this. Those recruited for participation in the Institute may be those who have early on indicated a passion and commitment to 4-H youth work and are thus more likely to stay. Another explanation may reside in local realities-lack of higher paying positions, connection to the community and other geographic factors which reduce the chances of re-locating.

Skill Development. As reported by the respondents, the Institute is effective at building professional skills and competencies for the majority of participants. Most indicated a high level of confidence and that their professional competence had improved. More than 90 percent felt that the Institute was valuable enough that it should be continued to be offered in the Western region. Because a majority of participants are early career professionals, this skill development is essential to providing support and orientation to the rigors of $4-\mathrm{H}$ youth development work.

Job Satisfaction. From those who responded to the survey, job satisfaction had increased from the time when they first participated in the Institute training. The greatest increase was in the "satisfied" response which showed an increase of 10 percent-a significant difference. Although there were no significant differences between the other ratings, there was a general shift towards greater job satisfaction after the passage of time since the training.

Interestingly, about a fourth of respondents had advanced in position or responsibilities since participating in the Institute training program. The reasons for this advancement, however, are 
not clear and warrant further study. Since so many of the participants are new to Extension, it would not be unusual for some advancement to occur as these employees gain more experience on the job.

Organizational Loyalty. As for building a close knit culture akin to a family environment, half of those who have been through the Institute training experience felt this was true, but a sizeable portion of the group is still undecided on this issue. Extension must do more to develop an organizational culture which includes everyone and supports everyone.

Early career employees apparently take some time to decide how viable their jobs are before dedicating themselves to it as a career. Some are so new that they cannot adequately assess the desirability of their current position relative to other options. Organizational loyalty runs shallow rather than deep with these respondents. Nearly half said that they might be looking for another job within the next year, and two-thirds said that they would willing to leave Extension if it were to their advantage to do so. Future research should look into the strength of organizational loyalties and what factors support or weaken these bonds.

\section{Summary}

For the 4-H organization, a regional training model for early career 4-H professionals appears to be a viable approach to fostering the skills and competencies necessary for new youth workers to succeed in their careers. Turnover is relatively low, and job satisfaction improves over time. In addition, these employees are likely to report that they intend to remain on the job. In our region of the country, where resources are scarce and training options are equally scarce, a regional training effort has proven effective to supporting new staff and faculty within-depth, lasting professional development.

Based on our experience, other national youth-serving organizations might also benefit from more regionalized trainings held on a regular basis. Training and support are often areas where new hires express the need for more help (Laroche \& Klein, 2008). "Sink or swim" has too frequently been the training model in youth development. Our experience shows that focused, early career professional development, the nurturing of professional networks, and fostering organizational loyalty can make a difference in staff turnover and job satisfaction.

When asked if the institute was worthwhile a participant of the 2002 Institute offered insights that may be keys to the success to the process:

"It (the institute) was relevant to my career stage. I had only been in Extension two years and was desperate for practical ideas. It was useful and had timely information. Information was presented from experienced colleagues through the West (I enjoyed this greatly). I actually turned in some of the presenters as possible outside reviewers for promotion and tenure. I enjoyed meeting with others who were new in their career also. It was the only training I've been too where we were given time to truly learn from others in attendance. It gave me a sense of well being that others were having the same struggles as I was having (as a new agent). I don't know if you are aware of it but when we (Institute participants) see each other at NAE4-HA or Western Region Leaders Forum we still make connections about the Institute."

As training dollars in Extension and other youth programs become ever more scarce in the future, others may want to consider a regionalized training model to augment limited national or local training programs. Our regional model has shown itself, after two cohorts, to be 
effective at providing in-depth training on core competencies to help employees be successful and minimize turnover and dissatisfaction. By reducing turnover and enhancing skills, we can effectively build a sustainable youth development workforce for the future.

\section{References}

Annie E. Casey Foundation. (2003). The unsolved challenge of system reform: The condition of the frontline human services workforce. Online:

http://www.aecf.org/upload/PublicationFiles/the\%20unsolved\%20challenge.pdf

Astroth, K.A. (2002). Western 4-H institute: Preparing the 4-H professional for success:

Evaluation Report I. (Bozeman: Montana State University. ERIC \#469-010. On-line:

http://www.eric.ed.gov/ERICDocs/data/ericdocs2sql/content storage 01/0000019b/80/1a/6d/4

$\underline{6 . p d f}$

Bowie, L., \& Bronte-Tinkew, J. (2006). The importance of professional development for youth workers. Research-to-Results. Child Trends, 2006-17. (December).

Bouffard, S., \& Little, P. (2004). Promoting quality through professional development: Issues and opportunities in the out-of-school time evaluation. No. 8: August. Boston: Harvard Family Research Project.

Garza, P., Borden, L.M., \& Astroth, K.A. (2004). Professional development for youth workers. New Directions for Youth Development, 104. San Francisco: Jossey-Bass.

Hastings, S., \& Lifer, C. (1988). 4-H PRK: Professional research and knowledge base final report. Mississippi State University and The Ohio State University.

Laroche, H., \& Klein, J.D. (2008). Lessons from the front lines: Factors that contribute to turnover among youth development workers. Journal of Youth Development, 2. Article 0803FA003. On-line: http://www.nae4ha.org/directory/jyd/jyd article.aspx?id=8abd7ee5-af0f$\underline{4 c 25-876 e-43 c 67545 e 94 d}$

Lindstrom, J. (2004). Evaluation of Participants of the 2002 Western 4-H Region Institute. Spokane, WA: Washington State University Extension Service. Unpublished evaluation report.

Resource Development Associates. (2006). Beacon Workforce Study. (February). San Francisco: Beacon Initiative.

Salary.com. (2006). 2005/2006 Employee Satisfaction \& Retention Survey. Online: http://www.salary.com

Stone, B., Garza, P., \& Borden, L. (2005). Attracting, developing and retaining youth workers for the next generation. Tucson: The University of Arizona.

Stone, B., \& Rennekamp, R. (2004). New Foundations for the 4-H Youth Development Profession: 4-H Professional Research, Knowledge, and Competencies Study, 2004. Conducted in cooperation with the National 4-H Professional Development Task Force. National 4-H 
Headquarters, CSREES, USDA. On-line: http://www.national4-hheadquarters.gov/library/4Hprkc study 010605.pdf

Walker, J., Dunhan, T., \& Snyder, E. (1998). Clubs and groups in the social education of young people. The Center (Winter): 20-27. Online:

http://www.fourh.umn.edu/resources/center/Center1998.html

Webb, L., Schultz, L., Chvilichek, S., Strickland, B., \& Waldren, D.E. (2006). Western 4-H institute: Preparing the 4-H professional for success: Evaluation Report II. (Boise, ID: University of Idaho Extension.) Unpublished evaluation report.

Yohalem, N., Pittman, K., \& Moore, D. (July, 2006). Growing the next generation of youth work professionals: Workforce opportunities and challenges. Houston, TX: Cornerstone for Kids.

Online: http://www.cornerstones4kids.org/images/next gen final reportRW1.pdf

(C) Copyright of Journal of Youth Development Bridging Research and Practice. Content may not be copied or emailed to multiple sites or posted to a listserv without copyright holder's express written permission. Contact Editor at: patricia.dawson@oregonstate.edu for details. However, users may print, download or email articles for individual use.

ISSN 2325-4009 (Print); ISSN 2325-4017 (Online) 